\title{
Pengaruh Konseling Antenal terhadap Penerimaan AKDR Pascasalin: Sebuah Uji Klinis Non Randomisasi
}

\author{
Abdul Faris $^{1}$, Soetrisno $^{2}$, Risanto Siswosudarmo 3 , Umar Malinta ${ }^{4}$ \\ ${ }^{1}$ RSU Anutapura Palu \\ ${ }^{2}$ Departemen Obstetri dan Ginekologi, Fakultas Kedokteran, UNS \\ ${ }^{3}$ Departemen Obstetri dan Ginekologi, Fakultas Kedokteran-Kesehatan Masyarakat dan Keperawatan, UGM \\ ${ }^{4}$ Departemen Obstetri dan Ginekologi, Fakultas Kedokteran, UNHAS \\ Korespondensi: abdulfaris62@yahoo.co.id
}

Submisi:23 Juli 2017; Revisi: 25 Agustus 2018; Penerimaan: 28 Agustus 2018

\begin{abstract}
Background: During postpartum period women have a high motivation to start using contraception and postpartum IUD is an ideal method to offer. The rate of IUD use is still low, $14.06 \%$ of all postpartum contraceptive use. This might be attributed to lack of information and counseling from health providers.

Objective: To compare the number of postpartum IUD used among groups of clients who were counseled during ANC and re-counseled during latent phase (exposed group), and group counseled during latent phase only (control group).

Method: This study was a prospective quasi-experimental or randomised clinical trial. The first group was those counseled during ANC and latent phase, and the second was those counseled at latent phase only. Chi square and relative risk were used for statistical test two proportions.

Result and Discussion: A total of 342 subjects who met inclusion and exclusion criteria were recruited. They consisted of the 210 subjects ( $61,4 \%$ ) for the first group and 132 subjects $(38,6 \%)$ for the second.

The rate of IUD used in the first group was 82 of 210 (39\%) and 30 of $132(22.7 \%)$ in the second, $R R 1,72(95 \% \mathrm{Cl} 1.20-2.46)$, p 0,002. The rate of IUD used was also significantly influenced by a history of IUD acceptor $R R 2,90$ with $95 \% \mathrm{Cl} 2.23-3.77$ ), a history of contraceptive used (RR 1,79 with95\% Cl 1,18-2,71) and a history of contraceptive counselling (RR 1,50 with $95 \% \mathrm{Cl} 1,03-2,19$ ).

Conclusion: Clients who were counseled twice (during ANC and repeated at latent phase) had higher rate of postpartum IUD used significantly than those who were counseled at latent phase only. Other factors that significantly affected the rate of postpartum IUD used were history of IUD acceptor, history of contraceptive used.
\end{abstract}

Keywords: Postpartum IUD; counseling; rate of postpartum IUD use; antenatal care

\begin{abstract}
ABSTRAK
Latar Belakang: Periode pascasalin merupakan saat dimana seorang wanita memiliki motivasi yang besar untuk memulai penggunaan alat kontrasepsi. Pemasangan AKDR pada periode ini dapat menjadi metode yang ideal pada beberapa wanita. Namun demikian, cakupan pelayanan AKDR pascasalin tidaklah menggembirakan, hanya berkisar $14,06 \%$ dari capaian KB pascasalin baru. Beberapa permasalahan yang teridentifikasi antara lain belum tersosialisasinya pelayanan KB pascasalin dengan baik. Konseling AKDR pascasalin pada saat yang tepat diharapkan dapat meningkatkan keikutsertaan metode kontrasepsi ini. Tujuan: Penelitian ini bertujuan untuk membandingkan angka pemasangan AKDR pascasalin antara kelompok klien yang dikonseling saat AAN dan saat fase laten (kelompok terpapar), dengan saat fase laten saja(kelompok kontrol).

Metode: Penelitian ini merupakan penelitian quasi experimental yang membagi subyek penelitian menjadi 2 kelompok. Kelompok 1 adalah kelompok klien yang dikonseling saat asuhan antenatal (AAN) dan saat fase laten dan kelompok 2 dikonseling saat fase laten saja. Hasil analisis data memakai chi square serta risiko elative untuk membandingkan 2 proporsi.

Hasil dan Pembahasan Penelitian ini melibatkan 342 subyek dengan rincian 210 subyek $(61,4 \%)$ dikonseling saat AAN dan fase laten, dan 132 subyek (38,6\%) diberikan konseling saat fase laten saja.

Angka pemasangan AKDR pada masing-masing kelompok adalah 82 dari 210 (39\%) pada kelompok paparan dan 30 dari 132 (22,7\%) pada kelompok kontrol dengan $R R$ 1,72 (95\% Cl 1,20 - 2,46), p 0,002. Angka pemasangan AKDR pascasalin juga dipengaruhi oleh riwayat AKDR (RR 2,90 dengan 95\% Cl 2,23 - 3,77), riwayat $K B$ umum sebelumnya ( $R R$ 1,79 dengan $95 \% \mathrm{Cl} 1,18-2,71)$, riwayat konseling $\mathrm{KB}$ sebelumya ( $\mathrm{RR} 1,50$ dengan $95 \% \mathrm{Cl} 1,03-2,19)$.

Kesimpulan: Klien yang dikonseling 2 kali, saat AAN dan diulang saat awal persalian, memiliki angka pemasangan AKDR pascasalin lebih tinggi secara bermakna dibandingkan klien yang dikonseling saat fase laten saja. Faktor lain yang secara signifikan berpengaruh terhadap penerimaan AKDR pascasalin adalah paling dominan riwayat AKDR, kemudian riwayat KB sebelumnya, dan riwayat konseling KB sebelumnya
\end{abstract}

Kata Kunci: AKDR pascasalin; asuhan antenatal; konseling; angka pemasangan 


\section{PENDAHULUAN}

Indonesia dengan perkiraan jumlah penduduk sebanyak 252 juta jiwa pada tahun 2014 menempati peringkat keempat dunia sebagai negara dengan jumlah populasi terbanyak. ${ }^{1}$ Program Keluarga Berencana (KB) yang digalakkan oleh pemerintah menjadi sangat penting sebagai upaya pengendalian peledakan penduduk. Pencapaian peserta KB aktif semua metode kontrasepsi yang diperoleh dari data Badan Kependudukan dan Keluarga Berencana Nasional (BKKBN) tahun 2012 menyebutkan jumlah akseptor Intra Uterine Device/AKDR 459.177 (7,46\%) peserta.

Terdapat tiga indikator tambahan yang berkaitan dengan KB dalam Millenium Development Goals (MDGs) 2015. Indikator tersebut adalah Contraceptive Prevalence Rate/angka kesertaan KB $(C P R)$, Age Specific Fertility Rate (ASFR), dan unmet need (pasangan usia subur yang membutuhkan pelayanan KB namun tidak dapat melaksanakannya dengan berbagai alasan). Target nasional indikator tersebut pada tahun 2015 adalah CPR sebesar 65\%, ASFR usia 15-19 tahun sebesar 30/1000 perempuan usia 15-19 tahun dan unmet need $5 \%{ }^{2}$

Dua indikator KB dalam sepuluh tahun terakhir tidak mengalami banyak kemajuan. CPR cara modern yang sudah meningkat pesat selama kurang lebih 10 tahun dari $47 \%^{3}$ menjadi $56,5 \%^{4}$, yang berarti meningkat sebesar $9,5 \%$, hanya naik $1,4 \%$ menjadi $57,9 \%$ dalam kurun waktu 10 tahun terakhir ini. ${ }^{4}$ Demikian juga persentase kelompok unmet need yang sudah menurun pesat selama kurang lebih 10 tahun dari $12,7 \%^{3}$ menjadi $8,6 \%{ }^{4}$, yang berarti mengalami penurunan sebesar $4,1 \%$, justru meningkat $0,5 \%$ menjadi $9,1 \%^{5}$ dan baru turun lagi sebesar $0,6 \%$ menjadi $8,5 \%{ }^{4}$; praktis penurunan persentase unmet need dalam kurun waktu 10 tahun terakhir ini hanya 0,1 persen. Masih jauhnya target kedua indikator program KB ini patut diduga berkontribusi terhadap landainya penurunan $\mathrm{AKI}$, dimana program KB merupakan salah satu upaya penurunan AKI di bagian hulu . ${ }^{2}$

Dalam Rakornas BKKBN tanggal 9 Februari 2017 dicanangkan pembaharuan target nasional (20152019) menurut SDKI 2017 adalah sebagai berikut TFR dari 2,6 menjadi 2,28; CPR dari 61,9\% menjadi $66 \%$ dan unmet need dari $11,4 \%$ menjadi $9,9 \%{ }^{6}$
Dalam upaya meningkatkan kesehatan ibu sasaran utama program KB adalah pada kelompok unmet need dan ibu pascasalin. Kehamilan yang tidak diinginkan pada ibu pascasalin akan dihadapkan pada dua hal yang sangat berisiko. Pertama, jika kehamilan diteruskan, maka kehamilan tersebut akan berjarak sangat dekat dengan kehamilan sebelumnya. Kedua, jika kehamilan diakhiri maka berpeluang untuk terjadinya komplikasi aborsi yang juga dapat berkontribusi terhadap kematian ibu. Oleh sebab itu, KB pascasalin merupakan suatu upaya strategis dalam penurunan AKI. Riskesdas 2007 mencatat sebanyak $17 \%$ total kehamilan merupakan kehamilan yang tidak diinginkan ${ }^{2}$. Bahkan dalam studi secara global angka kehamilan yang tidak diinginkan sebesar $40 \%$ dan di Asia sekitar 38\%. ${ }^{7}$

Sejauh ini cakupan pelayanan KB pascasalin masih belum menggembirakan. Berdasarkan Laporan Hasil Pelayanan Kontrasepsi Januari - Juli 2013 (BKKBN), cakupan KB pascasalin dan pasca keguguran dibandingkan dengan cakupan peserta KB baru masih sebesar 13,27 persen. Capaian tersebut juga masih didominasi oleh non MKJP (Metode Kontrasepsi Jangka Panjang) yaitu suntikan (52,49\%) dan pil (18,95\%), sementara capaian MKJP implan (8,08\%), AKDR (14,06\%), MOW $(3,27 \%)$ dan MOP (0,02\%). Beberapa permasalahan yang dapat diidentifikasi antara lain belum tersosialisasinya pelayanan KB pascasalin dengan baik. ${ }^{2}$

Masyarakat Kota Palu sangat heterogen. Penduduk yang menetap di kota ini berasal dari berbagai suku bangsa seperti Bugis, Makassar, Toraja, Mandar yang berasal dari Sulawesi Selatan dan Sulawesi Barat, Gorontalo, Manado, Arab, Jawa, Tionghoa dan Kaili yang merupakan suku asli dan terbesar di Sulawesi Tengah. Di Kota Palu dengan jumlah penduduk 367.342 jiwa, menurut data tahun 2015 terdapat 61.133 Pasangan Usia Subur (PUS). Dari jumlah itu yang menjadi peserta KB adalah 52.556 (85,97\%) PUS yang terdiri dari 19.868 peserta KB baru dan 32.688 peserta KB aktif. Dari jumlah PUS yang bukan peserta KB sebanyak 8.577 $(14,03 \%)$. Jumlah peserta KB yang menggunakan

AKDR sebanyak $10.358(19,71 \%)$ yang terdiri dari $8.942(27,4 \%)$ peserta KB aktif dan KB baru sebanyak $1.416(7,1 \%){ }^{8}$ Angka-angka ini tentunya masih berubah sesuai dengan dinamika berbagai faktor 
yg mempengaruhinya. Fakta yang ada dalam tahun tahun terakhir, pengampu upaya preventif, lebih banyak mengumpulkan data daripada melakukan intervensi nyata, dan koordinasi dan kolaborasi antar sektor, tidak lagi berjalan seperti dulu. Juga otonomi daerah membuat program nasional hanya dilaksanakan jika didukung oleh APBN. Kesemuanya ini tentunya dapat menghambat peningkatan peserta KB di masyarakat. Diperlukan pendekatan dan metode lebih tepat untuk mensiasatinya.

Dasar alasan untuk mengoptimalkan upaya KB pascasalin adalah karena periode pascasalin merupakan periode yang paling mudah untuk menerima kontrasepsi. Selain itu, kembalinya kesuburan seorang wanita setelah melahirkan dapat bervariasi. Pada sebagian wanita yang tidak menyusui anaknya masa subur dapat kembali setidaknya 4 minggu setelah melahirkan. Beberapa ibu yang menyusui anaknya akan kembali subur setelah 6 bulan pascasalin, dan sepertiga wanita kembali masa suburnya sebelum mulai menstruasi. ${ }^{9}$

Periode pascasalin merupakan masa yang penting untuk memulai kontrasepsi, namun masih kurang dimanfaatkan. Banyak hal yang berkontribusi terhadap kehamilan yang tidak diinginkan, meliputi kurangnya pengetahuan pasien, metode kontrasepsi yang tidak efektif, penggunaan kontrasepsi yang tidak konsisten, aktivitas seksual yang tidak direncanakan, dan kegagalan kontrasepsi. Dari beberapa faktor diatas yang sifatnya tergantung individu pasien, konseling KB merupakan faktor yang berada dalam ranah para klinisi. ${ }^{10}$

Tujuan pelayanan KB pascasalin adalah untuk mengatur jarak kehamilan/kelahiran, dan menghindari kehamilan yang tidak diinginkan, sehingga setiap keluarga dapat merencanakan kehamilan yang aman dan sehat. Pelayanan KB pascasalin dimulai dengan pemberian informasi dan konseling yang sudah dimulai sejak masa kehamilan. Tenaga kesehatan sebagai pemberi pelayanan memegang peranan penting dalam memberikan informasi dan konseling KB pascasalin kepada calon peserta KB. ${ }^{2}$ Penggunaan KB pascasalin pada wanita secara signifikan akan menurunkan angka mortalitas dan morbiditas maternal, menurunkan angka mortalitas dan morbiditas bayi baru lahir, mencegah risiko kehamilan tidak diinginkan, mencegah kehamilan yang tidak diinginkan pada wanita usia muda dan tua dimana risiko maternal dan bayi baru lahir paling tinggi, menurunkan insidensi aborsi, memberikan waktu ke wanita untuk memberi jarak kehamilan mereka, menurunkan jumlah kasus transmisi vertikal HIV/AIDS dari ibu ke bayi. ${ }^{9}$

Walaupun semua metode kontrasepsi dapat digunakan sebagai metode $\mathrm{KB}$ pascasalin, namun mengingat angka drop out (DO) yang cukup tinggi dalam penggunaan non MKJP, maka dalam memberikan pelayanan konseling klien diarahkan untuk memilih MKJP, seperti implan dan AKDR. Dengan MKJP, angka ketidakberlangsungan kontrasepsi (DO) diharapkan dapat ditekan atau dikurangi (Mujiati, 2013). Berdasarkan laporan BKKBN tahun 2014 disebutkan bahwa persentase peserta KB aktif menurut metode kontrasepsi pada tahun 2013 AKDR masih relatif sedikit yaitu 11,41\%, dan jumlah persentase KB baru AKDR pada tahun yang sama berjumlah 7,75 persen. $^{2}$

Cowman et al., (2013) menyebutkan bahwa periode pascasalin merupakan kesempatan unik untuk memberikan konseling kontrasepsi. Konseling kontrasepsi penting bagi wanita yang pernah memiliki pengalaman kehamilan yang tidak diinginkan dan yang memiliki risiko terjadinya kembali kehamilan yang tidak direncanakan. ${ }^{10}$

Pada periode pascasalin seorang wanita memiliki motivasi yang besar untuk memulai penggunaan alat kontrasepsi. Pemasangan AKDR pada periode ini bisa menjadi metode yang ideal pada beberapa wanita. ${ }^{11}$ Mujihartinah mengatakan bahwa dengan melakukan konseling berarti penyedia layanan kesehatan membantu klien dalam memilih dan memutuskan jenis kontrasepsi yang akan digunakan sesuai dengan pilihannya, disamping itu juga dapat membantu klien agar merasa lebih puas. Konseling yang baik juga akan membantu klien menggunakan kontrasepsinya lebih lama dan meningkatkan keberhasilan program KB. ${ }^{12}$

Konseling AKDR pascasalin idealnya dilakukan saat periode asuhan antenatal (AAN) agar pemberi konseling dapat memberikan perhatian kepada klien dan menjawab pertanyaan-pertanyaan mereka. Konseling pada periode AAN juga memberikan kesempatan kepada klien untuk berdiskusi dengan suami atau anggota keluarga, yang juga merupakan 
bagian penting dalam sebuah proses konseling. Bila konseling saat AAN tidak dapat dilakukan atau tidak tercatat dalam catatan AAN, maka konseling dapat dilakukan pada: 1) saat memasukkan pasien ke rawat inap 2) saat fase fase laten, 3) saat hari pertama pascasalin, 4) sebelum operasi sesar yang terjadwal.

Konseling AKDR pascasalin selama persalinan fase aktif tidak dianjurkan oleh karena stress persalinan. Kontraksi yang intens saat persalinan bukanlah waktu yang baik untuk melakukan informed choice penggunaan alat kontrasepsi, dan klien tidak cukup perhatian untuk memberikan persetujuan penggunaan KB. ${ }^{9}$

\section{METODE}

Penelitian ini merupakan jenis penelitian kuantitatif yaitu quasi experimental, non-Randomized Control Trial menggunakan dua kelompok. Kelompok pertama dikonseling saat AAN dan saat fase laten, dan kelompok kedua dikonseling saat fase laten saja.

Klien yang memenuhi kriteria yang datang saat AAN diberikan konseling dan dicatat dalam lembar penelitian. Apabila klien tersebut datang kembali saat fase laten (pembukaan serviks kurang dari $4 \mathrm{~cm}$ ), klien diberikan konseling kembali. Pada klien yang datang ke kamar bersalin saat fase laten dan belum pernah dikonseling saat AAN, klien dikonseling saat itu juga. Konseling AKDR pascasalin ditekankan pada pemasangan AKDR pascaplasenta. Dari kedua kelompok tersebut kemudian dihitung angka pemasangan AKDR pascasalin. Alur penelitian dapat dilihat pada gambar 1.

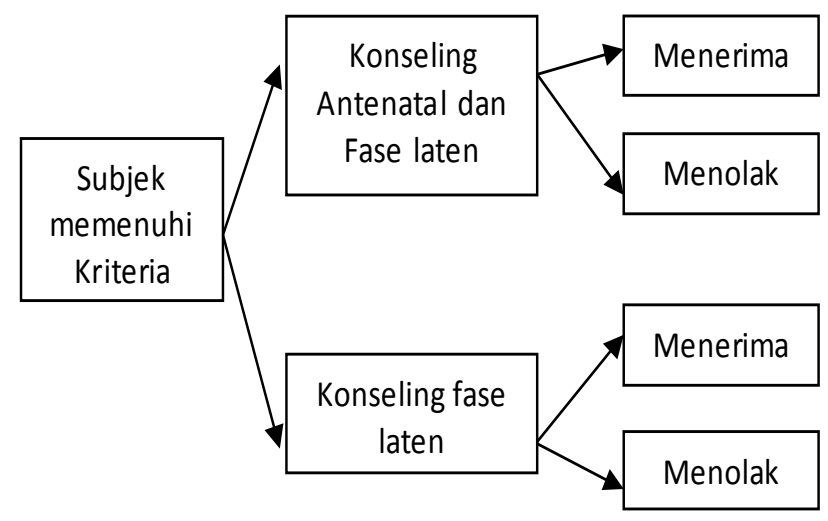

Gambar 1. Alur penelitian
Penelitian ini dilakukan di beberapa Rumah Sakit yaitu: RSU Anutapura Palu, RSUD Undata Palu, Rumkit Wirabuana Palu.

Kriteria inklusi yang ditetapkan adalah wanita hamil trimester ketiga yang melakukan pemeriksaan AAN di dan/atau bersalin di tempat penelitian yang bersedia menjadi subyek penelitian dan masih ada keinginan menggunakan AKDR sebagai alat kontrasepsi dimasukkan dalam penelitian ini. Sedangkan kriteria eksklusi adalah 1) memiliki tanda-tanda infeksi intrapartum, 2) terdapat kontraindikasi penggunaan AKDR, 3) yang melahirkan dengan ruptur perineum derajat 3 dan 4 serta dengan perdarahan pascasalin dini, dan 4) persalinan dengan kontraksi uterus yang lembek yang memerlukan terapi uetrotonika.

Besar subjek yang diharapkan 144 subyek tiap kelompok. Pada penelitian ini jumlah subjek yang diharapkan untuk kedua kelompok adalah 288 subyek.

Variabel yang diteliti dalam penelitian ini meliputi: variabel bebas yaitu 1) konseling antenatal dan fase laten, dan 2) konseling fase laten saja. Variabel tergantung adalah angka penerimaan AKDR pascasalin. Untuk variabel luar adalah a) umur, b) paritas, c) pendidikan, d) jenis kelahiran, e) riwayat AKDR sebelumnya, f) riwayat KB sebelumnya dan $g$ ) riwayat konseling KB sebelumnya.

Analisis data dilakukan secara kuantitatif yang disesuaikan dengan tujuan yang akan dicapai pada penelitian dengan uji statistik. menggunakan Uji Statistik Chi Square dengan tingkat kepercayaan $95 \%(\alpha=0,05)$. Analisis multivariat, menganalisis hubungan antara variabel bebas dengan variabel tergantung, dan pengaruh variabel luar menggunakan uji statistik regresi logistik.

\section{HASIL DAN PEMBAHASAN}

Penelitian ini melibatkan 342 subyek yang diambil dari 3 rumah sakitdengan karakteristik subyek pada tabel 4. 
Tabel 4. Karakteristik demografi subyek

\begin{tabular}{ll}
\hline \multicolumn{1}{c}{ Karakteristik } & $\mathrm{n}(\%)$ \\
\hline Paritas & \\
- Multigravida & $316(92,4)$ \\
- Primigravida & $26(7,6)$ \\
\hline Usia & $75(21,9)$ \\
- <20 th dan > 35 th & $267(78,1)$ \\
- 20 th - 35 th & \\
\hline Pendidikan & $46(13,5)$ \\
- $\leq 9$ th & $296(86,5)$ \\
- >9 th & $74(21,6)$ \\
\hline Jenis kelahiran & $268(78,4)$ \\
- Abdominal & \\
- Vaginal & $10(2,9)$ \\
\hline Riwayat kontasepsi AKDR sebelumnya & $332(97,1)$ \\
- Ya & \\
- Tidak & $242(70,8)$ \\
\hline Riwayat kontrasepsi sebelumnya & $100(29,2)$ \\
- Ya & \\
- Tidak & $239(69,9)$ \\
\hline Riwayat konseling KB sebelumnya & $103(30,1)$ \\
- Ya & \\
\hline
\end{tabular}

Pada penelitian ini 210 subyek (61,4\%) dikonseling saat AAN dan fase laten, 132 subyek $(38,6 \%)$ dikonseling saat fase laten saja. Komparabilitas antara kedua kelompok tersebut terlihat pada tabel 5 yang tampak bahwa data karakteristik kedua kelompok penelitian homogen.

Tabel 5.Komparabilitas antara dua kelompok

\begin{tabular}{|c|c|c|c|}
\hline & $\begin{array}{c}\text { Konseling saat AAN } \\
\text { dan fase laten } \\
\mathrm{N}(\%)\end{array}$ & $\begin{array}{c}\text { Konseling saat fase } \\
\text { laten saja } \\
\mathrm{N}(\%)\end{array}$ & Nilai $p$ \\
\hline $\begin{array}{l}\text { Usia (th) } \\
-<20 ;>35 \\
-20-35\end{array}$ & $\begin{array}{l}42(20,0) \\
168(80,0)\end{array}$ & $\begin{array}{l}33(25,0) \\
99(75,0)\end{array}$ & 0,28 \\
\hline $\begin{array}{l}\text { Paritas } \\
\text { - Multigravida } \\
\text { - Primigravida } \\
\end{array}$ & $\begin{array}{l}192(91,4) \\
18(8,6) \\
\end{array}$ & $\begin{array}{l}124(93,9) \\
8(6,1) \\
\end{array}$ & 0,39 \\
\hline $\begin{array}{l}\text { Pendidikan } \\
->9 \text { tahun } \\
\text { - } \leq 9 \text { tahun }\end{array}$ & $\begin{array}{l}186(88,6) \\
24(11,4)\end{array}$ & $\begin{array}{l}110(83,3) \\
22(16,7)\end{array}$ & 0,17 \\
\hline $\begin{array}{l}\text { Jenis Kelahiran } \\
\text { - Abdominal } \\
\text { - Vaginal }\end{array}$ & $\begin{array}{l}42(20,0) \\
168(80,0)\end{array}$ & $\begin{array}{l}32(24,2) \\
100(75,8)\end{array}$ & 0,35 \\
\hline $\begin{array}{l}\text { Riwayat KB AKDR } \\
\text { - Ya } \\
\text { - Tidak }\end{array}$ & $\begin{array}{l}9(4,3) \\
201(95,7)\end{array}$ & $\begin{array}{l}1(0,8) \\
131(99,2)\end{array}$ & 0,06 \\
\hline $\begin{array}{l}\text { Riwayat pernah KB sebelumnya } \\
\text { - Ya } \\
\text { - Tidak }\end{array}$ & $\begin{array}{l}156(74,3) \\
54(25,7)\end{array}$ & $\begin{array}{l}86(65,2) \\
46(34,8)\end{array}$ & 0,07 \\
\hline $\begin{array}{l}\text { Riwayat konseling KB sebelumnya } \\
\text { - Ya } \\
\text { - Tidak }\end{array}$ & $\begin{array}{l}154(73,3) \\
56(26,7)\end{array}$ & $\begin{array}{l}85(64,4) \\
47(35,6)\end{array}$ & 0,08 \\
\hline
\end{tabular}


Pengaruh konseling terhadap angka kelompok klien yang dikonseling dua kali, saat AAN pemasangan AKDR pascasalin terlihat pada tabel 6. Pada penelitian didapatkan perbedaan bermakna angka pemasangan AKDR pascasalin antara dan saat fase laten, dibandingkan kelompok klien yang dikonseling pada fase laten saja.

Tabel 6. Pengaruh waktu konseling terhadap penerimaan AKDR pascasalin.

\begin{tabular}{|c|c|c|c|c|c|}
\hline \multirow{2}{*}{ Waktu konseling } & \multicolumn{2}{|c|}{ AKDR } & \multirow{2}{*}{$\begin{array}{c}\text { Persentase } \\
\text { dipasang }\end{array}$} & \multirow{2}{*}{$R R(C l 95 \%)$} & \multirow{2}{*}{$p$} \\
\hline & Dipasang & Tidak & & & \\
\hline Saat AAN dan fase laten & 82 & 128 & 39,0 & $1,72(1,20-2,46)$ & 0,002 \\
\hline Saat fase laten saja & 30 & 102 & 22,7 & 1 & \\
\hline
\end{tabular}

Selanjutnya pengaruh variabel luar terhadap penerimaan AKDR pascasalin dapat dilihat pada tabel 7. Tampak bahwa variabel riwayat KB AKDR, riwayat konseling KB dan riwayat pernah KB sebelumnya secara statistik bermakna.

Tabel 7. Pengaruh variabel luar terhadap penerimaan AKDR pascasalin.

\begin{tabular}{|c|c|c|c|c|c|}
\hline & \multicolumn{2}{|c|}{ Dipasang AKDR } & \multirow{2}{*}{$\begin{array}{l}\text { Persentase } \\
\text { dipasang }\end{array}$} & \multirow{2}{*}{$R R(C l 95 \%)$} & \multirow{2}{*}{$p$} \\
\hline & Ya & Tidak & & & \\
\hline \multicolumn{6}{|l|}{ Usia (th) } \\
\hline - $<20 ;>35$ & 26 & 49 & 34,7 & $1,08(0,75-1,54)$ & 0,69 \\
\hline - $20-35$ & 86 & 181 & 32,2 & 1 & \\
\hline \multicolumn{6}{|l|}{ Paritas } \\
\hline - Multigravida & 107 & 209 & 33,9 & $1,22(0,99-1,49)$ & 0,13 \\
\hline - Primigravida & 5 & 21 & 19,2 & 1 & \\
\hline \multicolumn{6}{|l|}{ Pendidikan } \\
\hline - >9 tahun & 100 & 196 & 33,8 & $1,12(0,92-1,35)$ & 0,30 \\
\hline - $\leq 9$ tahun & 12 & 34 & 26,1 & 1 & \\
\hline \multicolumn{6}{|l|}{ Jenis kelahiran } \\
\hline - Abdominal & 30 & 44 & 40,5 & $1,32(0,95-1,84)$ & 0,10 \\
\hline - Vaginal & 82 & 186 & 30,6 & 1 & \\
\hline \multicolumn{6}{|c|}{ Riwayat KB AKDR } \\
\hline - Ya & 9 & 1 & 90,0 & $2,90(2,23-3,77)$ & 0,000 \\
\hline - Tidak & 103 & 229 & 31,0 & 1 & \\
\hline \multicolumn{6}{|c|}{ Riwayat pernah KB sebelumnya } \\
\hline - Ya & 91 & 151 & 37,6 & $1,79(1,18-2,71)$ & 0,003 \\
\hline - Tidak & 21 & 79 & 21,0 & 1 & \\
\hline \multicolumn{6}{|c|}{ Riwayat Konseling KB sebelumnya } \\
\hline - Ya & 87 & 152 & 36,4 & $1,50(1,03-2,19)$ & 0,03 \\
\hline - Tidak & 25 & 78 & 24,3 & 1 & \\
\hline
\end{tabular}

Variabel luar yang secara bermakna meningkatkan pemasangan AKDR pascasalin adalah riwayat pemakaian AKDR sebelumnya, riwayat pemakaian kontrasepsi umum sebelumnya dan riwayat konseling KB. Untuk mencari variabel mana yang paling berpengaruh terhadap angka pemasangan AKDR pascasalin dilakukan analisis multivariat yang dapat dilihat pada tabel 8. Tampak bahwa riwayat pemakaian AKDR sebelumnya paling dominan mempengaruhi pemakaian AKDR pascasalin $(p=0.001)$. 
Tabel 8. Analisis multivariat terhadap angka pemasangan AKDR pascasalin

\begin{tabular}{lccc}
\hline \multicolumn{1}{c}{ Variable } & $R R$ & $95 \% \mathrm{Cl}$ & $p$ \\
\hline $\begin{array}{l}\text { Riwayat pemakaian AKDR } \\
\text { - Ya }\end{array}$ & 13,06 & $1,50-113,62$ & 0,05 \\
$\begin{array}{l}\text { - Tidak } \\
\text { Riwayat KB umum sebelumnya }\end{array}$ & 1 & & \\
$\begin{array}{l}\text { - Ya } \\
\text { - Tidak }\end{array}$ & 12,06 & $1,23-118,76$ & 0,08 \\
\hline $\begin{array}{l}\text { Saat konseling } \\
\text { - AAN + FL }\end{array}$ & 1 & & \\
- FL saja & 3,18 & $1,90-5,32$ & 0,005 \\
\hline $\begin{array}{l}\text { Riwayat konseling } \\
\text { - Ya }\end{array}$ & 1 & & \\
- Tidak & & & \\
\hline
\end{tabular}

Pada penelitian ini angka penerimaan AKDR pascasalin pada klien yang diberikan konseling 2 kali, saat AAN dan saat fase laten sebesar $39 \%$ klien sedangkan pada klien yang dikonseling saat fase laten saja sebesar 22,7\% ( $R R$ 1,72 95\% Cl: 1,20 $2,46), p=0,002$. Dengan demikian didapatkan klien yang dikonseling dua kali akan meningkatkan angka pemasangan AKDR pascasalin 1,72 kali $(p<0,05)$. $\mathrm{Hal}$ ini serupa dengan penelitian yang dilakukan di Jogjakarta bahwa klien yang bersedia dipasang AKDR pascasalin yang diberikan konseling dua kali, saat AAN dan saat fase laten sebesar $52,8 \%$ dibandingkan klien yang dikonseling saat fase laten saja sebesar 30,7\% (RR 1,72 (95\% Cl: 1,24 - 2,37). ${ }^{13}$ Penelitian serupa yang dilakukan di Amerika Serikat yang mengatakan bahwa konseling yang dilakukan dua kali sejak sebelum persalinan dan setelah persalinan secara bermakna berhubungan dengan pemakaian metode kontrasepsi pascasalin bila dibandingkan dengan mereka yang tidak mendapatkan konseling sebelum persalinan. Mereka yang mendapatkan konseling sebelum persalinan juga lebih memilih metode kontrasepsi yang lebih efektif. ${ }^{14}$

Tingginya angka pemasangan AKDR pascasalin pada kelompok klien yang dikonseling dua kali, disebabkan pada saat konseling AAN klien dan keluarga memiliki waktu yang cukup untuk berdiskusi dengan petugas kesehatan sehingga membuat klien lebih termotivasi untuk memilih AKDR sebagai metode kontrasepsi yang dipilih. Kemudian dilanjutkan pada saat fase laten membuat klien dan keluarga yang belum cukup berdiskusi saat konseling pertama dapat menanyakan dan mengungkapkan permasalahannya pada konseling kedua. Klien yang dikonseling saat fase laten saja paling sedikit angka pemasangan AKDR pascasalin karena sempitnya waktu berdiskusi dengan petugas kesehatan dan rasa sakit akibat kontraksi rahim mulai menggangu klien dalam pengambilan keputusan. Pada saat fase laten petugas kesehatan juga cenderung fokus pada pertolongan persalinan dibandingkan memberi konseling KB.

Dari seluruh faktor luar yang mempengaruhi angka pemasangan AKDR pascasalin adalah riwayat pemakaian AKDR sebelumnya, riwayat menggunakan kontrasepsi sebelumnya dan riwayat konseling KB secara umum. Pada penelitian didapatkan angka pemasangan AKDR pascasalin yang bermakna pada kelompok klien yang memiliki riwayat penggunaan AKDR sebelumnya $p=0,000(p<0,05)$ dan ( $R R$ $2,9095 \% \mathrm{Cl} 2,23-3,77)$ dan riwayat pernah $\mathrm{KB}$ sebelumnya dengan $p=0,003(p<0,05)$ dan ( RR 1,79 $95 \% \mathrm{Cl} 1,18-2,71)$. Pada penelitian oleh Kurniawan didapatkan hasil yang sedikit berbeda yaitu angka pemasangan AKDR pascasalin bermakna pada kelompok klien yang memiliki riwayat penggunaan AKDR sebelumnya dan tidak bermakna pada klien dengan riwayat pernah KB. ${ }^{13}$ Pada penelitian oleh Yilmazel disebutkan adanya hubungan bermakna antara penggunaan kotrasepsisebelum hamil dengan keinginan menggunakan kontasepsi pascasalin. Dikatakan bahwa tingkat kepuasan penggunaan metode sebelumnya menjadi alasan untuk menggunakan kembali pada kontrasepsi pascasalin. Dari 10 subyek dengan riwayat penggunaan AKDR, 9 diantaranya menggunakan AKDR pascasalin. Tingkat 
kepuasan pada penggunaan AKDR sebelumnya akan meningkatkan motivasi klien untuk menggunakan kembali AKDR sebagai kontrasepsi pascasalin. ${ }^{15}$

Pada kelompok klien dengan riwayat konseling KB secara umum sebelumnya, angka penerimaan AKDR pascasalin meningkat secara bermakna $p=$ 0,007 ( $p<0,05$ ) dibandingkan dengan kelompok yang tidak pernah dikonseling sebelumnya (RR 1,50 $95 \% \mathrm{Cl} 1,03-2,19)$.

Dari faktor lain yang diteliti, meskipun tidak bermakna, terdapat kecenderungan meningkatkan angka pemasangan AKDR pasca salin pada kelompok usia $<20$ dan $>35$ tahun, multigravida dan pendidikan $>9$ tahun. Hasil yang agak berbeda terlihat pada hasil penelitian Kurniawan dimana angka pemasangan AKDR pascasalin meningkat meskipun tidak bermakna pada kelompok usia 2035 tahun, primigravida dan pendidikan $>9$ tahun. ${ }^{13}$

Penelitian yang dilakukan di Turki didapatkan hasil bahwa faktor usia, tingkat pendidikan dan jumlah anak tidak berpengaruh terhadap keinginan klien untuk menggunakan kontrasepsi pascasalin. ${ }^{15}$, Berbeda dengan penelitian di Malawi yang mengatakan faktor paling penting pada pengunaan KB pascasalin termasuk usia, pendidikan, jumlah anak yang dilahirkan, dan kunjungan oleh tenaga medis. ${ }^{16}$

Pada penelitian ini klien dengan pendidikan $>9$ tahun memiliki penerimaan AKDR lebih banyak dibandingkan klien dengan pendidikan $\leq 9$ tahun, akan tetapi tidak bermakna. Hampir serupa dengan penelitian kami, penelitian di Mesir (2003) dan di India (2012) mendapatkan hasil pendidikan formal meningkatkan peneriamaan AKDR pascasalin bila dibandingkan dengan yang tanpa pendidikan juga meningkatkan pengetahuan klien yang berpendidikan menengah keatas tentang perlunya menjaga jarak kehamilan dan perlunya metode kontrasepsi untuk mengatur jarak kehamilan. ${ }^{17} \mathrm{Hal}$ ini bertentangan dengan penelitian yang dilakukan di India dimana penerimaan AKDR lebih tinggi pada klien dengan pendidikan dasar dibandingkan pendidikan menengah, pendidikan tinggi dan pendidikan informal. ${ }^{18}$ Pada penelitian kami tingkat pendidikan klien memiliki efek positif terhadap penerimaan konseling. Hal ini mungkin dikarenakan klien dengan pendidikan lebih tinggi lebih mudah memahami materi konseling yang diberikan sehingga penerimaannya lebih tinggi, namun tidak signifikan.

Pada klien dengan usia $<20$ dan $>35$ tahun cenderung lebih menerima AKDR pascasalin dibandingkan usia 20-35 tahun meski hasilnya tidak berbeda bermakna. Penelitian yang dilakukan oleh Palamuleni menyebutkan umur secara signifikan mempengaruhi penggunaan kontrasepsi pascasalin di Malawi. Dijelaskan bahwa wanita dengan usia lebih muda cenderung menunda penggunaan kontrasepsi karena usia pernikahan yang baru membuat mereka belum ingin ber-KB. Sementara pada usia lebih tua dikatakan bahwa berkurangnya frekuensi hubungan seksual membuat kelompok ini cenderung tidak lagi memilih kontrasepsi. ${ }^{16}$

Klien dengan kehamilan pertama cenderung lebih menerima AKDR pascasalin dibandingkan dengan kehamilan kedua atau lebih, namun tidak berbeda bermakna. Hasil ini serupa dengan penelitian di India ${ }^{18}$ dan di Turki ${ }^{15}$ dimana wanita primigravida cenderung lebih menerima kontrasepsi pascasalin, namun tidak bermakna, dibandingkan wanita multigravida. Pada penelitian ini kelompok multipara lebih banyak menerima AKDR pascasalin karena kelompok ini sebagian besar memiliki pendidikan $>9$ tahun dan berusia $>35$ tahun.

Setelah dilakukan analisis multivariat untuk mengetahui variabel mana yang paling berpengaruh terhadap angka pemasangan AKDR pascasalin, diurutkan dari yang paling berpengaruh adalah sebagai berikut: riwayat penggunaan AKDR sebelumnya ( $R R$ 13,06; 95\% Cl 1,50 - 113,62) dan nilai $p=0,05$; riwayat KB sebelumnya ( $R R$ 12,06; $95 \% \mathrm{Cl} 1,23-118,76)$ dan nilai $p=0,08$; subyek yang mendapat dua kali konseling (saat AAN dan fase laten) dengan $R R$ 3,18; 95\% $C l 1,9-5,32$ ) dan nilai $p$ $=0,005$ serta yang terakhir adalah riwayat konseling KB sebelumnya ( $R R$ 2,27; 95\% Cl 1,31-3,95) dan nilai $p=0,16$. Dari hasil tersebut terlihat bahwa hanya konseling yang dilakukan dua kali (saat AAN dan fase laten) bermakna secara statistik maupun secara klinis mempengaruhi penerimaan AKDR pascasalin. Hasil yang agak berbeda terlihat pada penelitian yang dilakukan Kurniawan dimana urutan faktor yang berpengaruh adalah jenis kelahiran abdominal; riwayat pemakaian AKDR sebelumnya 
dan konseling saat AAN dan fase laten. ${ }^{13}$

\section{KESIMPULAN DAN SARAN}

Klien yang dikonseling dua kali, saat AAN dan diulang saat fase laten, memiliki angka pemasangan AKDR pascasalin lebih tinggi secara bermakna dibandingkan klien yang dikonseling 1 kali saat fase laten saja. Faktor lain yang secara signifikan berpengaruh terhadap penerimaan AKDR pascasalin adalah yang paling dominan riwayat pemakaian AKDR sebelumnya, kemudian riwayat KB sebelumnya, dan dan riwayat konseling KB sebelumnya.

Untuk meningkatkan angka pemasangan AKDR pascasalin setiap petugas kesehatan sebaiknya melakukan konseling sejak AAN dan diulang pada saat klien dalam fase laten proses untuk melahirkan. Apabila konseling saat AAN tidak dilakukan, konseling saat fase laten sebaiknya dilakukan.

Saran berdasar penelitian ini adalah lembar edukasi KB pascasalin dari BKKBN, dapat diganti menggunakan lembar konseling $\mathrm{KB}$ berimbang yang tidak membutuhkan waktu yang lama. Perlu dilakukan penelitian lain dengan mengendalikan variabel perancu yang belum diteliti seperti karakteristik suami, pendapatan keluarga, asuransi kesehatan.

\section{DAFTAR PUSTAKA}

1. Anonim. 2014. List of countries by population. Wikipedia.. Available at: http://en.wikipedia.org/ wiki/List_of_countries_by_population. diakses 1 Januari 2014

2. Mujiati I. 2013. Pelayanan KB pasca persalinan dalam upaya mendukung percepatan penurunan angka kematian ibu. Buletin Jendela Data dan Informasi Kesehatan. 2:11-16.

3. Indonesia - Survei Demografi dan Kesehatan Indonesia 1991, diunduh dari https://microdata.bps. go.id/mikrodata/index.php/catalog/256

4. Indonesia - Survei Demografi dan Kesehatan Indonesia 2002-2003 diunduh darihttps://microdata. bps.go.id/mikrodata/index.php/catalog/259.

5. Indonesia - Survei Demografi dan Kesehatan Indonesia 2007 diunduh dari https://microdata.bps. go.id/mikrodata/index.php/catalog/260/related_ materials.
6. BKKBN. 2017. Survei demografi dan kesehatan indonesia tahun 2017. Available at: https://www. bkkbn.go.id/detailpost/pertemuan-tim-pengarahdan-teknis-sdki-2017.

7. Sedgh G, Singh S \& Hussain R. 2014. Intended and Unintended Pregnancies Worldwide in 2012 and Recent Trends.

8. Habibullah M. 2015. Data demografi keluarga dan keluarga berencana serta tahapan KS Kota Palu tahun 2015. Badan KB dan Pemberdayaan Perempuan Kota Palu.

9. National Rural Health Mission. 2011. Counseling for postpartum family planning and postpartum IUCD.

10. Cowman W, Hardy-Fairbanks A, Endres J, and Stockdale CK. 2013: A select issue in the postpartum period: contraception the importance of providing postpartum contraception counseling. Proceedings in Obstetrics and Gynecology. 3(2): 1-15.

11. Kapp N dan Curtis KM. 2009. Intrauterine device insertion during the postpartum period: a systematic review. Contraception. 80 (4): 327-336.

12. Mujihartinah. 2009. Hubungan konseling keluarga berencana dengan kelangsungan penggunaan kontrasepsi AKDR di wilayah kota Tanjungpinang. Tesis S2. Fakultas Kedokteran UGM. Yogyakarta.

13. Kurniawan A. 2016. Perbandingan angka pemasangan AKDR pascasalin antara kelompok klien yang dikonseling sejak asuhan antenatal dengan saat persalinan saja. Tesis. Fakultas kedokteran UGM. Yogyakarta.

14. Zapata LB, Murtaza S, Whiteman MK, Jamieson DJ, Robbins $\mathrm{Cl}$, Marchbank PA, D'Angelo DV, Curtin KM. 2015. Contraceptive counseling and postpartum contraceptive use. Am J Obstet Gynecol. 212: 171e1$171 \mathrm{e} 8$.

15. Yilmazel G dan Balci E. 2013. Preferences and related factors for postpartum contraception in pregnant women. Iran J of Reprod Med., 11(10):801-806.

16. Palamuleni ME. 2015. Use and determinants of postpartum contraception among women in Malawi.: 1-16.

17. Mohamed SA, Kamel MA, Shaaban OM. 2003. Acceptability for the use of postpartum intrauterine contraceptive devices: assiut experience. Medical Principles and Practice. 12(3): 170-175.

18. Maluchuru S \& Aruna V. 2015. Post partum intrauterine device insertion - 2yr experience at a tertiary care center in guntur medical college govt general hospital, Guntur. IOSR Journal of Dental and Medical Sciences Ver. IV. 14(3): 2279-861. 